\begin{tabular}{|c|c|c|}
\hline $\begin{array}{l}\text { Editorial \& Publishing Offices : } \\
\text { MACMILIAN \& Co., LTdD. } \\
\text { ST. MARTIN’S STREET } \\
\text { LONDON, W.C.2 }\end{array}$ & is & $\begin{array}{l}\text { Telegraphic Address : } \\
\text { PHusis, LesQuARE, LoNDON } \\
\text { Telephone Number: } \\
\text { WHITEHALL } 883 \mathrm{I}\end{array}$ \\
\hline No. 3475 & SATURDAY, JUNE 6, 1936 & Vol. I37 \\
\hline
\end{tabular}

\title{
Native Labour from Nyasaland
}

$\mathrm{N}^{\Lambda}$ ATIVE labour, more especially after the great expansion of the mining industry, was for long one of the more insistent problems of the southern half of the African continent. Many causes combined to restrict the supply of labour, and while in time every effort was made to ensure that conditions should be as favourable to the native labourer as circumstances allowed, the authorities were even more exercised as to the means whereby the numbers seeking employment could be maintained at a figure adequate to the requirements of agriculture, mining and industry generally. After the failure of imported Chinese labour to meet this need in the early years of the present century, it became necessary for the labour-recruiting agencies to go farther and farther afield, until natives were being brought from districts very far removed from the provinces in which they were to be employed.

In these early days, the needs of industry and the call for the development of the resources of the country claimed to be, and were regarded as paramount. It was urged that any and every means, such as an increased hut tax or encouragement of the habit of purchasing European necessities or luxuries, might legitimately be used to induce or compel the native to work over and above that required for his bare level of subsistence. In justification of such argument, it has to be admitted that as the native mind has become familiarised with the idea of wage-earning, the opportunity afforded by the recruiting agent has suggested the most ready, if not indeed the only, means of meeting the deficit in the individual, or rather family, budget caused by taxation, even when it has not opened a road to the acquisition of European luxuries, or wealth in the form of cattle.
The introduction and employment of native labour on a considerable scale in the mines imposed upon the authorities the obligation to look with care to the well-being of the employed. Not only has this obligation been recognised, but also on the whole it has been met to the full, especially in the oversight of the conditions of employment, and in regard to health, housing and general welfare in the labour compounds of the mines. Yet even so, it has been recognised, as a rule, that this system of native labour entails certain consequences and changes in the character of the individual, which are not entirely beneficial, and may indeed in certain conditions be regarded as incurring the risk of inflicting positive harm.

So much may be stated, as a necessary intro. duction, of the case to be made out for the needs of industry and development in relation to the supply of native labour, and the obligation thereby imposed to provide some measure of protection for the labourer as an individual. There is, however, another side to the picture, which events of recent years have brought to the front. $\mathrm{Ad}$. ministrative difficulties due to the loosening of the bonds of tribal custom and collective responsibility in the repatriated labourer have directed attention to the effect of labour-recruiting on the area from which labour is drawn. Africa is no more immune from the effects of labour recruitment than the islands of the Pacific, which have furnished labour for the plantations. Experience has shown that in both areas the absence of virtually the whole of the able-bodied younger men for a more or less prolonged period affects adversely the increase and the morale of the tribe, while im. perilling its social and economic stability.

An example of the disturbance caused by such a removal of a large part of the able-bodied 
population, and the lengths to which it may go, is afforded by the Protectorate of Nyasaland. Here, as is shown by the recently published report of a Committee appointed by the Governor in 1935 to inquire into the conditions and effects of native migration for the purpose of seeking employment abroad, the situation is such as to constitute a serious menace to the future of population and country alike. The Committee, in fact, gives warning that unless the causes of migration are controlled and counteracted, the economic entity of the country will be imperilled, large tracts of land rendered unfit for cultivation, in the native community immorality and disease will be almost universal, and the native will hate administration by white people, which has been responsible for such results.

Could an indictment more grave be framed against an administration, which, so far from being oppressive, has on the whole been wellintentioned in its aims? That such a state of affairs should now be allowed to exist, or even that such possibilities could be envisaged for the future, argues a failure to appreciate native character and custom, which should be incredible in these days of intensive scientific study of the close-knit texture of African institutions. An outworn tradition has been allowed to survive too long. Nyasaland, since the early days of labour migration in South and Central Africa, has been known as a fertile source of man-power. For twenty-five years, that is up to 1935, labour recruiting has not been permitted within the borders of the Protectorate. This policy, no doubt, at the time of its inception was thought to be in the interests of the native. It was a mistake. Although the number of the inhabitants now outside the country is not known with certainty, it is estimated that they do not fall short of 120,000 . As the labourers have sought employment independently, they have lost the advantage of the organisation and safeguards which apply to the labour-recruiting agencies. They have suffered untold hardships and privations in travel; the wages offered them have been low ; and they have been victimised at the hands of unscrupulous employers and others; while no arrangements have been made to remit the money they came to earn to their families, or for their own safe return to their homes. In fact, it is found that 25-30 per cent of the emigrants never return. Either they die-as they are not subjected to medical examination for fitness, the rate of mortality is high - or they marry foreign women, or they never earn, or they spend, the money they needed, and are unable or ashamed to return home.

Such are the facts which the Committee established; and on them it comments that, although the state of affairs was known to be grave, as inquiry proceeded the Committee became more and more aware that "this uncontrolled and growing emigration brought misery and poverty to hundreds and thousands of families and that the waste of life, happiness, health and wealth was colossal".

In the month of June, 1935, the Governor announced that an exclusive three-year contract had been granted to a private company permitting the engagement of labour in the Northern Province for employment in Southern Rhodesia and the Union of South Africa. It is permissible to expect that this contract will serve as a safeguard against the worst of the evils affecting the migrant labourer to which attention has been directed. Up to the present, however, it has had little effect on native migration as a whole. In probing the causes which induce the native to migrate, the Committee, while allowing something to the love of adventure, places first economic necessity. The native needs cash wherewith to pay his hut or poll tax, and as he cannot earn it locally, he must seek employment abroad.

In making its recommendations as to how the situation which has arisen may best be remedied, the Committee, in view of its findings, turns first of all to the possibility of improving the economic position of the native population by openings which would serve as an alternative to emigration. It is recommended that agricultural surveys should be made of the large areas of the Pro. tectorate which have not yet been surveyed; and it is suggested further that the native should be trained to adapt himself and his methods of cultivation to changing conditions. The only crop, however, which it is thought would meet native requirements of a ready cash return without involving too arduous labour, is cotton. On the other hand, it is the view of the Committee that certain changes in the incidence of taxation might press less hardly on the women, and reduce migration from certain undeveloped areas. In order to control the movement of labour, a system of registration such as that practised in Southern Rhodesia, Kenya and elsewhere is recommended, or alternatively a form of tax receipt which would prove identity. 
Of the Committee's recommendations, by far the most obviously attractive is that which suggests the extension of the native's economic capacity by the cultivation of cotton, although clearly it is closely bound up with a number of questions, such as transport, markets, distribution and the like, which can only be discussed after a close and detailed study of both local and extraterritorial conditions.

The importance of the labour supply in Africa suggests that the problem with which the Nyasaland Administration is faced cannot be settled finally without consideration of its ramifications outside the boundaries of the Protectorate. To deal only with its internal aspects may raise more serious issues elsewhere. One method of bringing the wider question of the supply of labour into debate is perhaps indicated by the recommendation of the Committee that, in the interest of the control of recruiting, statutory agreements should be made with neighbouring territories. Such agreements would seem to imply a thorough ventilation of the whole position. Whatever may be the ultimate decision as to the action to be taken on the Committee's report, it is clear that a perilous situation has arisen out of Government action in imposing taxation. Almost any demands on the time and thought of the Administration in finding a way out could not be regarded as excessive.

\section{In Search of Truth of Earth}

The Land: Now and To-morrow

By Prof. R. G. Stapledon. Pp. xviii $+336+12$ plates. (London: Faber and Faber, Ltd., 1935.) 15s. net.

"Do you like playing with dirt ? I do." (Small boy looking over rail into pit at navvy shovelling out earth.-Punch, April 8, 1936.)

$\mathrm{O}^{\mathrm{U}}$ T of the mouths of babes and sucklings cometh wisdom! Prof. Stapledon would have us all play with dirt. From no happier than this child's point of view can the enthralling vital message of his book be construed. He would have us all learn to know and love the land like innocent little children and be alive to its value. Strange to say, this is no matter of course. We know ourselves to be of the earth earthy; we are built of it, with sole aid of the sun, around a germinal nucleus in which lie hidden the potent templates of life ; yet unfortunately we have little if any thought of our parentage. In an age nominally of great scientific progress, we are inconsiderately schooled to no useful purpose ; we take no real care of ourselves, have not the slightest curiosity to know ourselves; we hand ourselves over to a control which is ignorant, mostly. As a people, we have probably gone back steadily in intelligence since the opening of our schools in 1870-because our teachers have not been taught in the right way.

"In a rapt ecstatic way", we worship the far-off heavens and are even spending two millions in making a new telescope; we jubilantly hoist the mystical electron aloft as our scientific lodestar. In real life, we rain high explosives and poison from the air upon defenceless peoples. Few give a thought for the soil : not ten per cent of our population is engaged in its service. There is nowhere a professor either of agriculture or of agricultural chemistry who is a practical farmer -with full feeling for the soil, let alone the growing plant. The seat of the academic research worker but revolves upon the laboratory stool-life in the open has neither attraction nor meaning for him. Man is not a living soul to-day. Nor will the leaf soon be allowed to show itself in vital greenunder the highest scientific patronage, the poor hop is no longer allowed to grow unless plastered over with Bordeaux mixture: in fact, the vine everywhere is sicklied o'er with a by no means pale cast of vitriolic blue: the farce must soon cease or we ourselves shall be poisoned off by copper being everywhere. Natural growth is not studied: Nature is everywhere forcibly fed. The student is trained to think only in terms of statistical yields. At a college enjoying multiple county council support, trials are made year after year of the growth of barley upon laboriously randomised plots. The result is reported with great flourish of mathematical precision and calculation of probable errors in a most absurd way as the whole of such 'research' is in real error : nitrogen, we learn, in the end, is of benefit to the crop. Shade of Sir John Lawes-what say you to this?

It were time that we ceased from working at random in agriculture-that we had a clear conception what agriculture is to do for us as a nation. This, in fact, is Prof. Stapledon's main desire and purpose. As things are, we not only take no 